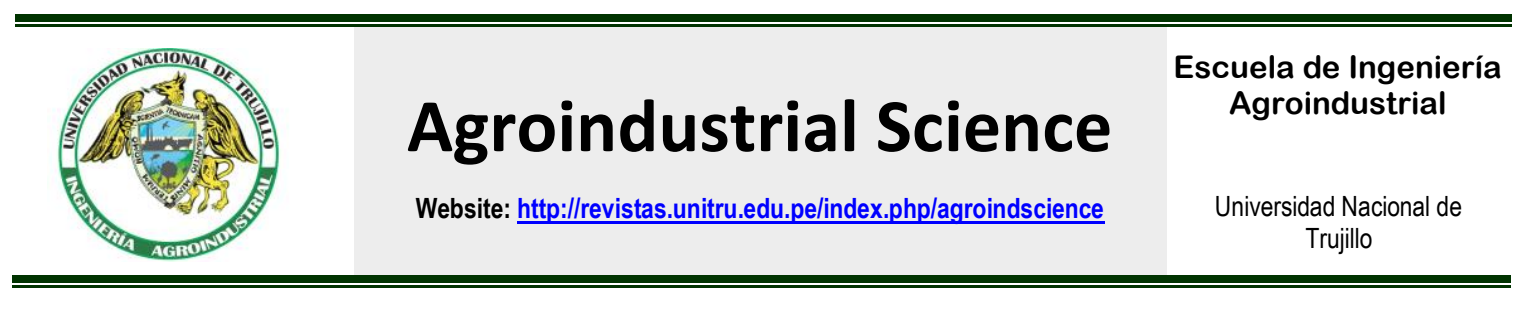

\title{
Osmotic dehydration in native fruits (Mammea americana L. and Mammea americana $L$.) and vegetables (Capsicum annuum L.) of the Amazon region

\author{
Deshidratación osmótica en frutas (Mammea americana L. y Mammea americana L.) y \\ hortalizas (Capsicum annuum $L$ ) nativas de la región Amazonas
}
Aníbal Quinteros 1,; Enrique Terleira1; Jaime Ramírez 1; Patricia García1; Richer Garay 1; Publio Castro2; Julio Chumacero ${ }^{3}$

\footnotetext{
1 Facultad de Ingeniería Agroindustrial, de la Universidad Nacional de San Martín, Tarapoto, San Martín, Perú

2 Facultad de Ciencias Agrarias, Universidad Nacional Autónoma de Chota, Chota, Cajamarca, Perú.

3 Facultad de Agronomía, Universidad de Buenos Aires, Buenos Aires, Argentina.
}

\begin{abstract}
RESUMEN
Los productos nativos de la región Amazonas como el mamey, aguaymanto y pimentón están considerados como alimentos funcionales con una demanda creciente, pero con problemas de comercialización debido a su alta perecibilidad y al deficiente manejo postcosecha. El objetivo del presente trabajo fue elaborar frutas y hortalizas desecadas mediante deshidratación osmótica, utilizando solución azucarada como agente osmótico. El tratamiento preliminar que fueron sometidos las muestras fue por separado, esto debido a que las muestras en estudio presentan características propias, sin embargo, todas estas fueron sometidas a los mismos tratamientos de deshidratación osmótica a temperaturas de $35^{\circ} \mathrm{C}, 45$ ${ }^{\circ} \mathrm{C}$ y $55^{\circ} \mathrm{C}$ y a $30,40,50$ y $60{ }^{\circ}$ Brix según correspondía. La cinética de deshidratación osmótica de la pérdida de agua y ganancia de sólidos en el mamey (Mammea americana), la aguaymanto (Physalis peruviana L.), pimentón (Capsicum annuum $L$ ) presentaron una buena respuesta en disoluciones a $60^{\circ}$ Brix y $55^{\circ} \mathrm{C}$ y el equilibrio es alcanzado a las 8,11 y 7 horas respectivamente. Asimismo, el coeficiente de difusividad, presentan diferencia significativa con respecto al factor de la temperatura y la estructura interna, el área y la piel de contacto del producto influyen en gran medida en el proceso de deshidratación osmótica de los tres productos en estudio.
\end{abstract}

Palabras clave: deshidratación osmótica; pérdida de agua; ganancia de sólidos; coeficiente de difusividad

\section{ABSTRACT}

Native products from the Amazon region such as mamey, aguaymanto and paprika are considered as functional foods with a growing demand, but with marketing problems due to their high perishability and poor postharvest handling. The objective of the present work was to prepare dried fruit and vegetables by osmotic dehydration, using sugar solution as an osmotic agent. The preliminary treatment that the samples were submitted was separately, this because the samples under study have their own characteristics, however all of them were subjected to the same osmotic dehydration treatments at temperatures of $35^{\circ} \mathrm{C}, 45^{\circ} \mathrm{C}$ and $55^{\circ} \mathrm{C}$ and $30,40,50$ and $60^{\circ}$ Brix as appropriate. The osmotic dehydration kinetics of water loss and solids gain in mamey (Mammea americana), aguaymanto (Physalis peruviana L.), paprika (Capsicum annuum L) presented a good response in solutions at $60^{\circ}$ Brix and $55^{\circ} \mathrm{C}$ and the equilibrium is reached at 8,11 and 7 hours respectively. Also the diffusivity coefficient, present significant difference with respect to the factor of the temperature and the internal structure, the area and contact skin of the product have a great influence on the osmotic dehydration process of the three products under study.

Keywords: osmotic dehydration; water loss; solids gain; diffusivity coefficient.

\section{Introduction}

The beginning of the new millennium, the interaction food-medicine has given rise to the development of the so-called functional foods. A functional food is one that contains a component, nutrient or no nutrient, with selective activity related with one or several functions of the organism, with a physio- logical effect added above its nutritional value and whose positive actions justify that its functional nature can be claimed (physiological) or even healthy (Silveira et al., 2003).

This global trend guides the industry to the development of a wide range of products that besides nourishing, are safe and healthy for the 
well-being of its customers (Pérez, 2006; Estrada et al., 2017). Some of the functional products are found in fruits and vegetables that besides of having a variety of nutrients, contain elements for the good performance of the organism such as fiber and bioactive compounds, called phytochemicals that are a potential source of antioxidants, micronutrients, vitamins, carbohydrates, minerals, bioactive, among others (Torija, 2014; VergaraValencia et al., 2015). However, despite its high demand, fruits and vegetables have a low volume of commercialization, because they are seasonal and perishable products, there are losses of raw materials up to $40 \%$ due to the precarious conditions of post-harvest handling in producing areas, causing huge losses to farmers and health hazard (Cook, 2007).

Among the conservation techniques that allow to obtain a processed food product, with added value and long service life, there is osmotic dehydration and drying by cabins.

Osmotic dehydration is a technique that that involves immersing the raw material in aqueous solutions of solutes (sugars and/or salts) with high osmotic pressure. The driving force required for water flow is the difference in chemical potential between the solution and the intracellular fluid. If the cell membrane is perfectly semipermeable, the solute is unable to diffuse into the cells. Therefore, the phenomenon presents two simultaneous countercurrent processes: the movement of water from the food to the hypertonic solution, in which some of the food components can be dragged together with the extracted water and, the impregnation of the food with the solutes that come from the solution (Mascheroni, 2010; Fito y Chiralt, 2000). The use of osmotic dehydration in the food industry as a pretreatment allows partial dehydration of the food, improving the quality of the product in terms of color, flavor and texture with a minimum energy requirement.

For the aforementioned, the objective of this work was to produce dried products based on native fruits (mamey, aguaymanto and paprika) from the Amazon region, using osmotic dehydration.

\section{Material and methods}

The investigation project was developed in The research project was developed in the Research and Development laboratory of the Faculty of Agroindustrial Engineering of the National University of San Martin-T, located in the University campus, District of Morales, Province and Department of San Martín.
Conditioning of the samples for dehydration. Mamey samples (Mammea americana L.) were collected from the district of Tabalozos, department of San Martín, in a semi-mature state. Subsequently, the fruit was selected, peeled and cut into pieces of slices uniformly with dimensions: width 1.5 $\mathrm{cm}$, length $2.5 \mathrm{~cm}$ and thickness $1 \mathrm{~cm}$ so that the solution is transferred to the interior of the fruit. In the case of aguaymanto (Physalis peruviana L.) the raw material was obtained from alluvial fields in the town of Juan Guerra. We proceeded to select fruits according to their quality attributes: uniform diameter between 1.5 and $2 \mathrm{~cm}$, with weights between 3 and $4 \mathrm{~g}$, with a content of soluble solids between 13 and $14{ }^{\circ}$ Brix and free of impurities, finally they are peeled to facilitate mass transfer and physically-chemically characterized. Finally, for the paprika (Capsicum annuum $L$ ) the raw material came from the market of supplies of the city of Tarapoto, taking into account the degree of maturity that is reflected in the texture of the vegetable, which must be firm and reddish, they were selected and classified rejecting the immature or soft, the raw material was classified as suitable when it had a good texture so it will not change during the osmotic dehydration. The samples were conditioned to an average of $4.0 \mathrm{~cm}$ in length and $1.0 \mathrm{~cm}$ diameter. Before the osmotic dehydration process, the raw material was washed manually in a $0.1 \%$ solution of sodium hypochlorite to eliminate foreign agents and the microbial load. Also, the raw material was submerged in a solution of $10 \% \mathrm{NaCl}$ for $24 \mathrm{~h}$, having a raw material - saline solution ratio of $1: 3$ in proportion, the purpose of this operation was to extract the mucilages, pectins, latex and certain sugars that can influence the osmotic dehydration, as well as the water of the intercellular spaces. Later the desalination was carried out with abundant water until the brackish taste disappeared, during a time of $4-12 \mathrm{~h}$, at room temperature. The blanching was carried out at $100{ }^{\circ} \mathrm{C}$ for 3 minutes in a water bath (MEMMERT) with this is possible to increase the permeability of the tissues in the samples. Finally, the vegetable was drained using basket.

\section{Elaboration of dehydrated fruits}

The elaboration of dehydrated fruits was carried out in two stages, in the first stage, vegetables and fruits were dipped in syrups of increasing concentrations and at constant temperatures of $35{ }^{\circ} \mathrm{C}, 45{ }^{\circ} \mathrm{C}$ and $55^{\circ} \mathrm{C}$ as appropriate. The initial syrup was at $30{ }^{\circ}$ Brix (70\% water and $30 \%$ sugar), with sample-syrup ratio 1:3. The samples were placed in $500 \mathrm{ml}$ beakers, which contained the 
syrup then the mixture was stirred (CAT Model M5), during three hours, after that time it was processed to repeat the operation in syrups of 40,50 and $60^{\circ}$ Brix.

Once the osmotic dehydration process was finished, the samples were drained for 15 minutes and sprayed with water at a temperature of $80^{\circ} \mathrm{C}$, to facilitate the elimination of honey impregnated in the vegetable.

Finally, drying was carried out by the stove at $60^{\circ} \mathrm{C}$ for $24 \mathrm{~h}$, once this operation had elapsed, the samples were packed in polyethylene bags, which were hermetically sealed in order to ensure the complete isolation of the surrounding environment.

\section{Characterization of the raw material}

In the raw material, humidity, $\%$ soluble solids ( ${ }^{\circ}$ Brix), Water activity (W), Acidity, average weight, average diameter, average fruit weight and average pulp weight are determined.

\section{Characterization of dehydrated fruit}

In the dehydrated fruit the following analyses were carried out.

Water loss

The moisture content was determined by a triplicate gravimetric method, according to AOAC 930.04 (AOAC, 1990).

Gain of Solids

To determine the gain of solids in relation to the initial mass of the product, we used the following equation.

$$
S G(\%)=100((s t-s o) / m 0) \quad \text { eq.1 }
$$

Where, SG: Percent gain of solids with respect to the initial mass, st: Initial dry matter in the (g), s0: dry matter at a time $t$ in the product $(\mathrm{g}), \mathrm{m} 0$ : Initial mass of the product $(\mathrm{g})$.

\section{Determination of the Diffusivity Coefficient}

To determine the diffusivity, the Crank's equation was used for $F_{0}>0.20$, which is the following:

$$
Y=\frac{Z o-Z t}{Z o-Z \infty}=1 \frac{\mathrm{g}}{\pi^{2}} \exp \left[\pi^{2} * \frac{D_{e f} * t}{4 *\left(\frac{e}{2}\right)^{2}}\right]
$$

Zo: initial ${ }^{\circ}$ Brix $(t=0)$

Zt: ${ }^{\circ}$ Brix in balance

$\mathrm{e}=$ Thickness of the mamey

Def: Effective diffusivity

From equation (3), we clear diffusivity:

In the same way to calculate the liquid phase of the fruit (FLF) in terms of driving force, the following equation was used:

$$
Y=\left(\frac{Z_{t}-Z_{c}}{Z_{0}-Z_{c}}\right) \quad \text { eq. } 3
$$

Where:

Zt: Soluble initial ${ }^{\circ}$ Brix in the liquid phase of the fluid at a time $t$

Z0: ${ }^{\circ}$ Brix at zero time in the liquid phase of the fluid

$\mathrm{Zc}$ : ${ }^{\circ}$ Brix of the osmotic solution.

\section{Experimental design}

For the present investigation, a Completely Random Experimental Design was used, with a factorial arrangement $3{ }^{*} 2 * 3$ having as factors the optimum temperature of the process $\left(35^{\circ} \mathrm{C}, 45^{\circ} \mathrm{C}\right.$ and $55^{\circ} \mathrm{C}$ ), and concentration of sucrose 40,50 and $60{ }^{\circ}$ Brix and with a level of significance of $5 \%$, the reliability of the data will be evaluated by the coefficient of variation (CV) and the coefficient of determination $\left(R^{2}\right)$.

The analysis of variance was evaluated, as well as Tukey's comparative tests based on the samples at the temperatures and concentration of sucrose using the statistical package SAS System for Windows V9.2) and Statistica V10.

\section{Results and discussion}

\section{Physicochemical analysis of the Raw Material}

The physicochemical analyzes performed on the mamey (Mammea americana) (Table 1) shows that it is a fruit with high water activity $0.989 \pm 0.01$, and data related to those mentioned by Alegre et al., (2016) who determined humidity for the mamey of 85.26 , soluble solids $12.05 \pm 0.23, \mathrm{pH}$ of $3.19 \pm$ 0.17 and percentage of acidity 0.004 .

Table 1

Physicochemical composition of mamey (Mammea americana L.)

\begin{tabular}{lc}
\hline Parameters & Exp values \\
Physicochemical & $85.3 \pm 0.56$ \\
\hline Humidity $(\%)$ & $11.37 \pm 1.13$ \\
Soluble Solids ( ${ }^{\circ}$ Brix $)$ & $0.98 \pm 0.01$ \\
Water activity & $4.60 \pm 0.82$ \\
pH & $586.68 \pm 4.96$ \\
Average weight $(\mathrm{g})$ & $12.25 \pm 4.58$ \\
Average diameter $(\mathrm{cm})$ & $0.29 \pm 0.15$ \\
Acidity $(\%)$ & $800.3 \pm 7.93$ \\
W fruit $(\mathrm{g})$ & $680.40 \pm 6.95$ \\
W pulp $(\mathrm{g})$ & \\
\hline
\end{tabular}

Regarding aguaymanto the results obtained indicate that it is a fruit with acidic characteristics, with a high activity of water and high content of sugars. The physicochemical composition of the evaluated aguaymanto (Table 2) showed differences to the data reported by Mendoza et al. (2012) that in their 
work obtained values of $6.76 \mathrm{pH}\left(2{ }^{\circ} \mathrm{C}\right), 3.72$ titratable acidity (mg citric acid / $100 \mathrm{mg}$ of sample), 1.27 total soluble solids ${ }^{\circ}$ Brix, 15.91 total sugars ( $\mathrm{mg} / \mathrm{ml}$ of sugar) and water activity 0.998 , being able to have as source of variation the origin or edaphoclimatic conditions where the samples were extracted.

Table 2

Physicochemical composition of Aguaymanto (Physalis peruviana L.)

\begin{tabular}{lc}
\hline Parameters Physicochemical & Exp values \\
\hline fruit /skin weight(g) & $4.6 \pm 0.78$ \\
Fruit W $(\mathrm{g})$ & $4.41 \pm 0.79$ \\
Skin W $(\mathrm{g})$ & $0.19 \pm 0.03$ \\
Thickness $(\mathrm{cm})$ & $1.87 \pm 0.06$ \\
Length $(\mathrm{cm})$ & $1.95 \pm 0.08$ \\
$\mathrm{~N}^{\circ}$ of fruits $/ 100 \mathrm{~g}$ & 92 \\
Weight $100 \mathrm{~g}$ & $437 \pm 2.34$ \\
Water activity (\%) & $0.99 \pm 0.01$ \\
Acidity (\%) & $2.14 \pm 0.18$ \\
Soluble solids ( ${ }^{\circ}$ Brix) & $13.40 \pm 0.80$ \\
pH & $3.52 \pm 0.16$ \\
\hline
\end{tabular}

Table 3

Physiochemical composition of Paprika (Ls)

\begin{tabular}{lc}
\hline Parameters Physicochemical & Exp values \\
\hline Fruit W $(\mathrm{g})$ & $44.32 \pm 3.54$ \\
Thickness $(\mathrm{cm})$ & $3.61 \pm 0.20$ \\
Length $(\mathrm{cm})$ & $8.9 \pm 0.55$ \\
Water activity $(\%)$ & $0.88 \pm 0.77$ \\
Acidity $(\%)$ & $0.2 \pm 0.25$ \\
Soluble solids ( ${ }^{\circ}$ Brix) & $9 \pm 0.01$ \\
pH & $5.9 \pm 0.11$ \\
\hline
\end{tabular}

Finally, the results obtained in the paprika (Table 3) do not agree with those reported by Mendoza (2013), which in their studies obtained that the content of soluble solids in paprika was 3.5; water activity 0.966 and $\mathrm{pH} 6.47$. Understanding that this difference is due to the difference of the state of the samples (Mendoza et al., 2012).

\section{Determination of water loss (WL)}

In the corresponding figures to the water loss in mamey (Figure 1), aguaymanto (Figure 2) and paprika, the information described by Di Bernardo (1988) and Vega-Gálvez et al. (2007) that mention that in the course of time there is a greater loss of humidity of the product and increase of the loss of solids in the solution. If the time and concentration of the solution are increased, the water mass variation will be higher; and if the temperature increases the loss of water is even greater. The highest variation occurs with the treatment at a concentration of $60 \%$ and a temperature of $55^{\circ} \mathrm{C}$. Likewise, in the treatments is observed the principle that characterizes the osmotic dehydration that is distinguished for the initial increase in water loss, followed by a lower rate of water loss in later stages (Andrade et al., 2007; Azoubel and Murr, 2004; Mercali et al., 2011).

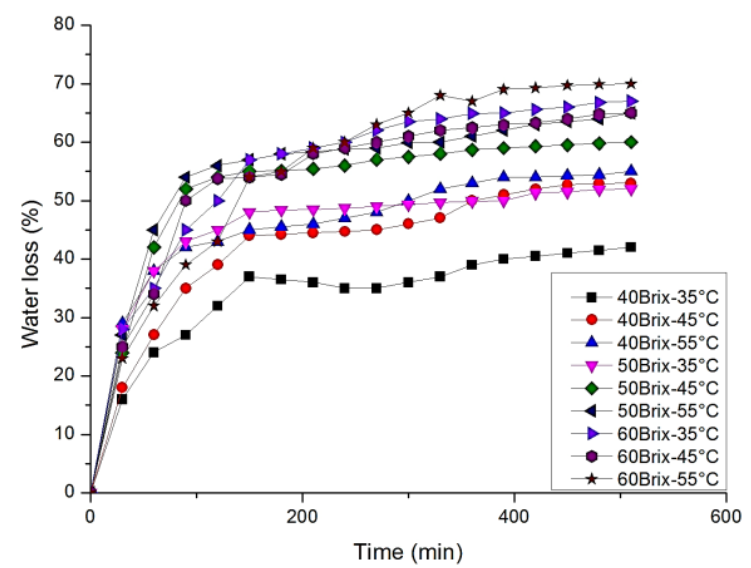

Figure 1. Water loss behavior of the mamey pieces (Mammea americana), osmotically dehydrated at 40,50 and 60 Brix at the temperatures of 55,45 and $35^{\circ} \mathrm{C}$.

In the case of the increasing trend with temperature, the observed data are consistent with the results found with mamey and aguaymanto that indicate that increasing the temperature improves water loss in food materials during osmotic dehydration, which are attributed to the swelling and plasticization of cell membranes, what results in a faster and better distribution and evacuation of water that improves mass transfer characteristics (water) in the part of the surface of the product, due to a decrease in viscosity of the osmotic medium (Heng et al., 1990; Lazarides et al., 1999).

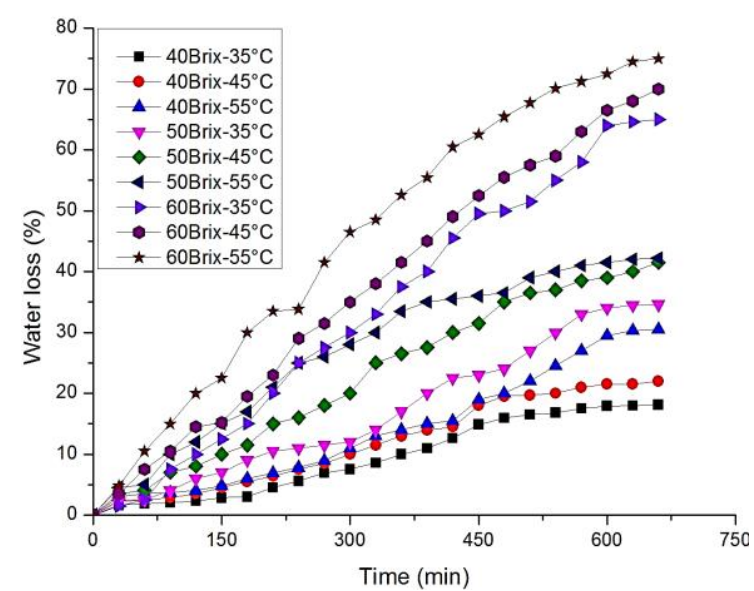

Figure 2. Water loss behavior of aguaymanto (Physalis peruviana L.), osmotically dehydrated at 40,50 and 60 Brix at the temperatures of 55,45 and $35^{\circ} \mathrm{C}$. 


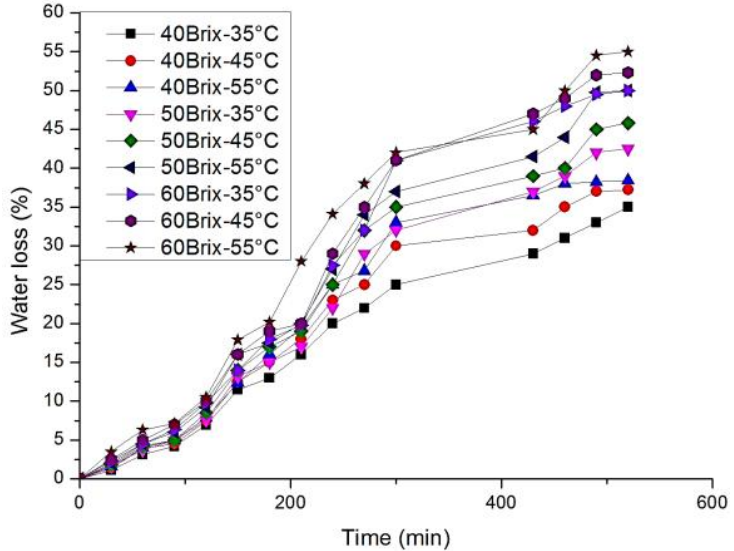

Figure 3. Water loss behavior of paprika (Capsicum annuum $\mathrm{L}$ ), osmotically dehydrated at a concentration of 40,50 and $60{ }^{\circ}$ Brix at a temperature of 55,45 and 35 ${ }^{\circ} \mathrm{C}$.

\section{Determination of the solids gain (SG)}

In Figure 4, corresponding to slices of mamey, it was observed that the gain of solids (SG\%) during 10 hours of dehydration is greater in treatments that have the highest temperature and concentration (60 brix and $55^{\circ} \mathrm{C}$ ) and the one that had lower gain of solids was the treatment of 40 brix and $35{ }^{\circ} \mathrm{C}$. According to Amie (2007), temperature significantly influences the gain of soluble solids that is influenced by temperature, because increases in temperatures directly affect the permeability of the cell membrane, allowing greater intake of solutes in the product.

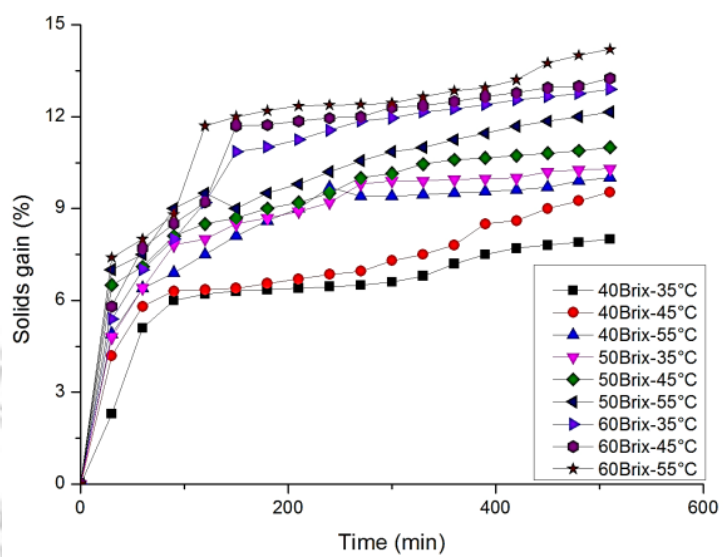

Figure 4. Solids gain behavior of mamey pieces (Mammea americana), osmotically dehydrates at 40, 50 and 60 Brix at the temperatures of 55,45 and $35^{\circ} \mathrm{C}$.

For the case of aguaymanto (Figure 5) and paprika (Figure 6), the gain of solids is an important measure factor in osmotic dehydration, because its increase can favor the creation of a barrier on the surface of the product that affects negatively the transfer of mass in the system (Giraldo et al., 2003).

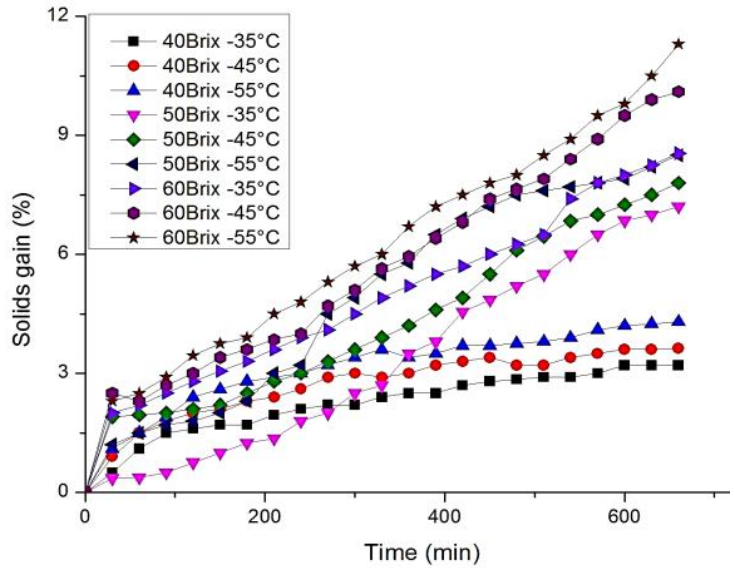

Figure 5. Solids gain behavior of aguaymanto (Physalis peruviana $\mathrm{L}$ ), osmotically dehydrated at 40,50 and 60 Brix at the temperatures of 55,45 and $35^{\circ} \mathrm{C}$.

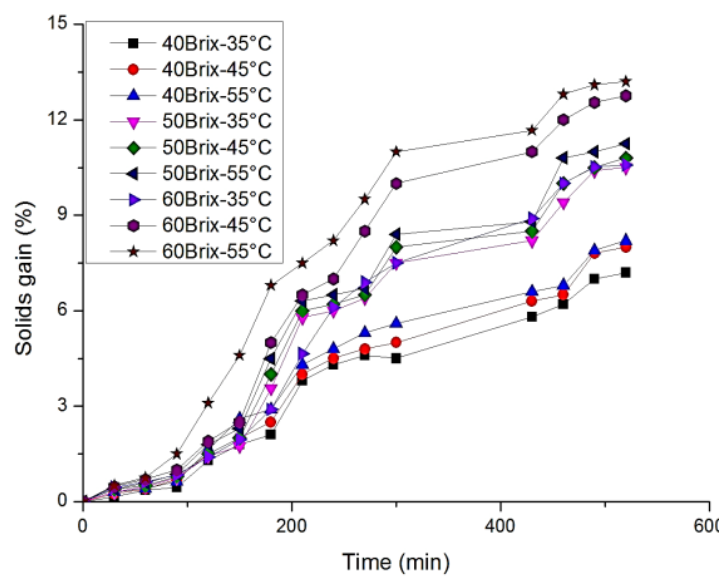

Figure 6. Solids gain behavior of paprika (Capsicum annuum $\mathrm{L}$ ), osmotically dehydrated at 40,50 and 60 Brix at the temperature of 55,45 and $35^{\circ} \mathrm{C}$.

\section{Diffusion coefficient of water}

By analyzing the effective diffusivity for water loss (WL) during dehydration in mamey pieces (Figure 7); an analysis of variance was obtained where there is a significant difference with respect to temperature with a coefficient of determination of $89.4 \%$ and the effect of the non-significant interaction. It is also observed that the values of greater diffusivity were for the treatments that have higher concentration of solids at the temperature of $45{ }^{\circ} \mathrm{C}$ at 40,50 and $60{ }^{\circ}$ Brix their experimental values $9.52 \times 10^{-9}, 9.54 \times 10^{-9}$ y $9.57 \times 10^{-9}\left(\mathrm{~m}^{2} / \mathrm{s}\right)$, respectively while the lowest values were given at 35 ${ }^{\circ} \mathrm{C}$ at 40,50 and $60{ }^{\circ}$ Brix and values $9.06 \times 10^{-9}$, $8.84 \times 10^{-9}$ and $9.29 \times 10^{-9}\left(\mathrm{~m}^{2} / \mathrm{s}\right)$.

Gracey (2012) affirms that statistically the temperature turns out to be the significant factor, this confirms the obtained in the present work where the factor of the temperature directly influences the osmotic dehydration existing significant differences between the treatments. 


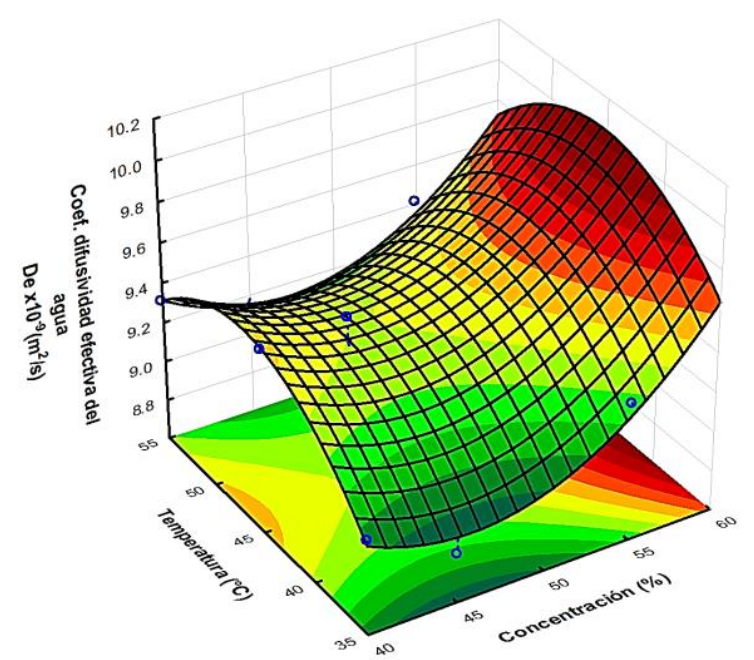

Figure 7. Diffusivity coefficient of mamey pieces (Mammea americana), osmotically dehydrated at a concentration of 40,50 and $60^{\circ}$ Brix at a temperature of 55,45 and $35^{\circ} \mathrm{C}$.

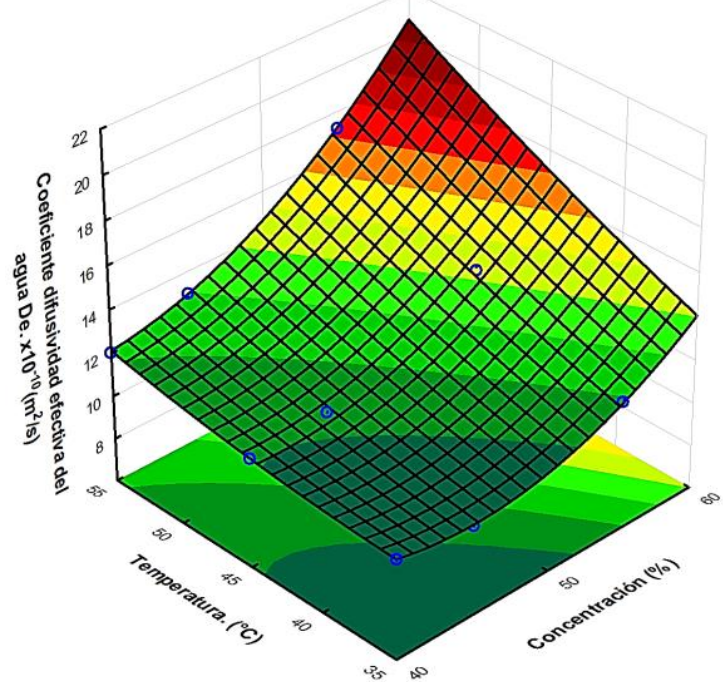

Figure 8. Diffusivity coefficient of aguaymanto pulp (Physalis peruviana L.), osmotically dehydrated at a concentration of 40,50 and 60 Brix at 55,45 and $35^{\circ} \mathrm{C}$.

The statistical analysis to evaluate the interaction or influence of incorporation of sucrose in aguaymanto during the osmotic dehydration process was carried out through the analysis of variance and it was possible to verify that all the effects were significant and showed a positive effect on the incorporation of sucrose. The temperature and sucrose concentration were the factors with the greatest statistical significant difference, followed by the interaction between the variables. The model of the coefficient determination in the coefficient diffusivity in the incorporation of sugar (SG) during the process of osmotic dehydration of aguaymanto ( $R^{2}:$ : 0.999) within the temperature ranges of 35 to $55^{\circ} \mathrm{C}$ and the concentration of solution of Osmotic sucrose 40 to $60^{\circ}$ Brix (Figure 8 ).
The diffusivity of paprika's water (Figure 9) increased when the temperature and the field strength increased. The regression coefficients (R2) for the computed values varied from 0.9803 to 0.99 , which showed a good relationship between moisture loss and time. This effect was generally attributed to the influence of the membranes of natural tissues, as well as to the diffuse properties of water and solutes as a function of their respective molar mass.

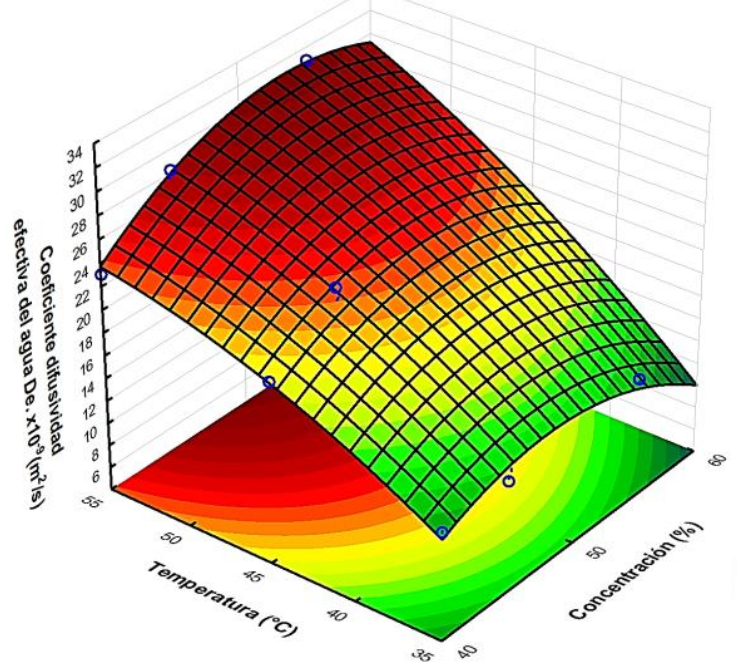

Figure 9. Diffusivity coefficient of paprika (Capsicum annuum $L$ ), osmotically dehydrated at a concentration of 40,50 and 60 Brix at 55,45 and $35^{\circ} \mathrm{C}$.

The effects observed in these products were attributed to the influence of the membranes of natural tissues, as well as to the diffuse properties of water and solutes as a function of their respective molar mass. It is observed that there is greater diffusivity as the sucrose concentration increases and as the temperature increases, this happens due to the structural characteristics of the fruit as indicated by Luchese et al. (2015).

\section{Conclusions}

With respect to the results obtained, it can be said that the experimental design showed that the behavior increases, with different transfer speeds of matter, both water and soluble solids, depending on the concentration and temperature of the solution.

The internal structure, the area and the contact skin of the product greatly influence the osmotic dehydration process of mamey (Mammea americana), aguaymanto (Physalis peruviana L.), paprika (Capsicum annuum L). The kinetics of osmotic dehydration of water loss and solids gain present a good response in solutions at $60^{\circ}$ Brix 
and $55^{\circ} \mathrm{C}$ and the equilibrium is reached at 8,11 and 7 hours respectively.

The kinetics of osmotic dehydration in the diffusivity coefficient of mamey (Mammea americana), aguaymanto (Physalis peruviana L.), paprika (Capsicum annuum L), present a significant difference with respect to the temperature factor.

\section{References}

Alegre, C.; Linares, G. 2016. Efecto de la temperatura y concentración de miel de abeja sobre la cinética de deshidratación osmótica, y aceptabilidad general en la elaboración de snacks de mamey (Mammea americana). Revista de investigación de estudiantes de ingeniería 2(1): 1-15

Andrade, S.A.C.; Neto, B.B.; Nobrega, A.C., Azoubel, P.M.; Guerra, N.B. 2007. Evaluation of water and sucrose diffusion coefficients during osmotic dehydration of jenipapo (Genipa americana L.). Journal of Food Engineering 78: 551-555.

AOAC.1990. Oficial Methods Of Análisis. 15 ht ed., Vol. 1. K. Helrich, Ed. USA: Association of Official Analytical Chemist, Inc.

Amie, R. 2007. Influencia de la temperatura en la difusividad efectiva y características sensoriales de cubos de yacon (Smallanthus sonchifolius) deshidratado osmo convectivamente. Trujillo, Perú: Tesis para optar el Título; Profesional de Ingeniero agroindustrial. Universidad Nacional de Trujillo. $101 \mathrm{pp}$.

Azoubel, P.M.; Murr, F.E.X. 2004. Mass transfer kinetics of osmotic dehydration of cherry tomato. Journal of Food Engineering 61: 291-295.

Cook, R. 2007. Tendencias internacionales en el sector de frutas y hortalizas. Economía Agraria 181: 183 -208.

Di Bernardo, L. 1988. Sedimentación Convencional y Laminar. Copias para el curso de maestría para la Facultad de Ingeniería de la UNI Lima.

Estrada, L., Saumett, H.; Iglesias, M.; Bahamón, M.; Cáceres, A.; Restrepo, C.;. Diáz, A. 2017. Productos de Confitería nutracéutica: una opción empresarial para cultivadores de frutas y hortalizas. Barranquilla - Atlántico: Ediciones Universidad Simón Bolivar.

Fito, P.: Chiralt, A.; Betoret, N.; Gras, M.: Cháfer, M.; Martınez-Monzó, J.; Vidal, D. 2001. Vacuum impregnation and osmotic dehydration in matrix engineering: Application in functional fresh food development. Ed. S.M. Alzamoa 49(2-3): 175-183.
Giraldo, G.; Talens, P.; Fito, P.: Chiralt, A. 2003. Inf luence of sucrose solution concentration on kinetics and yield during osmotic dehydration of mango. J. Food Eng. 58(1): 33-43

Gracey, C.R. 2012. Efecto de la concentración y temperatura de jarabes de fructosa y sacarosa invertida en las características fisicoquímicas y aceptación sensorial de cubos de mango. Available at: http://dspace.unitru.edu.pe/handle/UNITRU/1023

Heng, K.; Guilbert, S.; Cuq, J.L. 1990. Osmotic dehydration of papaya: Influence of process variable on the product quality. Science Aliments 10: 831-848.

Lazarides, H.N.; Katsanidis, E.; Nickolaidis, A. 1995. Mass transfer Kinetics during osmotic preconcentration a iming at minical solid uptake. Journal Food Engineering 25(2): 151-166.

Luchese, C.L.; Gurak, P.D.; Marczak, L.D.F. 2015. Osmotic dehydration of physalis (Physalis peruviana L.): Evaluation of water loss and sucrose incorporation and the quantification of carotenoids. LWTFood Science and Technology 63(2): 1128-1136.

Mascheroni, R. 2010. Secado de alimentos por métodos combinados: Deshidratación osmótica y secado por microondas y aire caliente. Universidad Tecnológica Nacional. Facultad Regional de Buenos Aires. Tesis para optar el grado de maestro, Buenos Aires.

Mendoza, Ch.J.H.; Rodríguez, S.A.; Millán, P. 2012. Caracterización físico química de la uchuva (Physalis peruviana) en la región de Silvia Cauca. Biotecnología en el Sector Agropecuario y Agroindustrial 10(2): 188 - 196

Mendoza Sánchez, L.G. 2013. Propiedades fisicoquímicas y antioxidantes del chile jalapeño (Capsicum annuum var. annuum) fresco y seco.

Mercali, G.D.; Marczak, L.D.F.; Tessaro, I.C.; Noreña, C.P.Z. 2011. Evaluation of water, sucrose and $\mathrm{NaCl}$ effective diffusivities during osmotic dehydration of banana (Musa sapientum, shum.). LWT e Food Science and Technology 44: 82-91.

Pérez, H. 2006. Nutraceúticos: componente emergente para el beneficio de la salud. Instituto Cubano de Investigaciones de los Derivados de la Caña de Azúcar XL(3): 20-28.

Silveira, M.; Monereo, M.; Molina, B. 2003. Alimentos funcionales y nutrición óptima icerca o lejos? Revista Española de Salud Pública 77(3): 317 - 332.

Torija, E. 2014. Alimentos de la huerta y sus Características funcionales. XIII Jornada del Grupo de Horticultura y I Jornada del Grupo de Alimentación y Salud.

Vergara-Valencia, N.; Granadoz-Pérez, E.; Agama-Acevedo, E.; Tovar, J.; Ruales, J.; Bello-Pérez, L. 2007. Fibre concentrate from mango fruit: Characterization, associated antioxidant capacity and application as a bakery product ingredient. LWT - Food Science and Tecnoloy 40(4): 722 - 729. 